\title{
PEMENUHAN HAK ANAK ATAS KESEHATAN DI PROVINSI NANGGROE ACEH DARUSSALAM DI DASARKAN QANUN ACEH NOMOR 11 TAHUN 2008 TENTANG PERLINDUNGAN ANAK
}

\author{
Andri Kurniawan \\ Fakultas Hukum Universitas Syiah Kuala Banda Aceh \\ E-mail: andri.kurniawan82@yahoo.com
}

\begin{abstract}
Qanun Aceh No. 11 of 2008 concerning Protection of Children is based on the perspective that protection of children in all aspects is a part of the development activities and distinctive peculiarities of Aceh and promoting community life and nation in the Republic of Indonesia. Obligation to provide protection to children based on the principles of non-discrimination, the best interests of the child, right to life, survival, and development, and reward for the opinions of children. In the implementation, legal protection of children in Nanggroe Aceh Darussalam not fully comply. Those constraint relating with the legislation, the body builder, body organizer, health facilities and membership.
\end{abstract}

Keywords : Qanun, Protection of the Child, Rights of the Child on Health

\begin{abstract}
Abstrak
Qanun Aceh Nomor 11 Tahun 2008 Tentang Perlindungan Anak didasarkan pada pemikiran bahwa perlindungan anak dalam segala aspeknya merupakan bagian dari kegiatan pembangunan kekhususan dan keistimewaan Aceh dan memajukan kehidupan bermasyarakat dan berbangsa dalam Negara Kesatuan Republik Indonesia. Kewajiban memberikan perlindungan kepada anak didasarkan pada asas Nondiskriminasi, Kepentingan yang terbaik bagi anak, Hak untuk hidup, kelangsungan hidup, dan perkembangan, dan Penghargaan terhadap pendapat anak. Dalam implementasinya, perlindungan hukum terhadap anak di Provinsi Nanggroe Aceh Darussalam belum sepenuhnya terpenuhi. Kendala yang dihadapi berhubungan dengan peraturan perundang-undangan, badan pembina, badan penyelenggara, sarana kesehatan dan kepesertaan.
\end{abstract}

Kata Kunci : Qanun, Perlindungan Anak, Hak Anak Atas Kesehatan

\section{Pendahuluan}

Qanun Aceh Nomor 11 Tahun 2008 Tentang Perlindungan Anak telah mencantumkan tentang hak anak, pelaksanaan kewajiban dan tanggung jawab orang tua, keluarga, masyarakat, pemerintah Aceh dan pemerintah kabupaten/ kota untuk memberikan perlindungan pada anak sebagai landasan yuridis bagi pelaksanaan kewajiban dan tanggungjawab tersebut. Dengan demikian, pembentukan Qanun Aceh No. 11 Tahun 2008 Tentang Perlindungan Anak di dasarkan pada pertimbangan bahwa perlindungan anak dalam segala aspeknya merupakan bagian dari kegiatan pembangunan kekhususan dan keistimewaan Aceh, memaj ukan kehidupan bermasyarakat dan berbangsa dalam Negara Kesatuan Republik Indonesia.

Anak merupakan generasi, asset, dan pemilik masa depan bangsa dan negara. Oleh karenanya kemajuan bangsa/negara ditentukan oleh pembinaannya sejak dini, ${ }^{1}$ Dalam kaitan ini, orang tua, keluarga, dan masyarakat diorientasikan untuk bertanggung jawab menjaga dan memelihara hak asasi anak sesuai dengan kewajiban yang dibebankan berdasarkan ketentuan peraturan perundang-undangan. Didasar-

Hambali, "Hak Anak atas Pendidikan; Pemenuhan Hak dan solusinya (Dimulai dari Pendidikan Keluarga dan aktivitas Sederhana)", J urnal Paradigma, XII (24) JuliDesember 2007, IKIP Budi Utomo Malang, hlm. 153 
kan penjelasan tersebut Pemerintah, Pemerintah Aceh dan Pemerintah Kabupaten/ Kota bertanggungjawab menyediakan fasilitas kesehatan yang dibutuhkan dan terjangkau dalam pemenuhan hak anak atas kesehatan, terutama dalam menjamin hak tumbuh kembang secara optimal dan terarah.

Pada dasarnya, anak sesuai dengan kodratnya adalah rentan, bergantung kepada orang lain dan memiliki kebutuhan-kebutuhan khusus. Oleh karena itu, anak memerlukan perawatan dan perlindungan yang khusus agar mereka bisa berkembang secara penuh, baik secara fisik maupun mental, dalam keluarga yang harmonis.

Penganiayaan atau penyiksaan kepada anak dalam bermacam-macam bentuk. Anakanak yang menjadi korban dari klaim hak milik bersama dengan segala akibatnya, disia-siakan, diperas tenaganya untuk kepuasan seks, diperlakukan dengan semena-mena, diperjualbelikan dan diperdagangkan, menjadi korban baik sebagai orang sipil maupun sebagai tentara di bawah umur, dan menjadi korban kekerasan yang dilakukan oleh banyak negara totaliter. Ini sangat fundamental yang berhubungan dengan pandangan anak perlu diperhatikan dalam setiap pengambilan keputusan yang akan mempengaruhi kehidupan dan perkembangan anak. ${ }^{2}$

Pemerintah Provinsi Nanggroe Aceh Darussalam perlu melakukan upaya untuk mencegah dan mengantisipasi terjadinya pelanggaran pemenuhan hak atas kesehatan. Upaya tersebut diantaranya adalah, pertama, menyediakan pelayanan kesehatan yang komprehensif, merata dan berkualitas, pemenuhan gizi seimbang, pencegahan penyakit menular termasuk HIV dan AIDS, pengembangan lingkungan dan perilaku hidup sehat; kedua, menyediakan pelayanan pendidikan yang merata, bermutu dan demoktratis bagi semua anak sejak usia dini; ketiga, membangun sistem pelayanan sosial dasar dan hukum yang responsif terhadap kebutuhan anak agar dapat melindungi anak dari

\footnotetext{
Tarmizi, "Penegakan Hukum Atas Pelanggaran Hak Asasi Anak di Banda Aceh", J urnal IImiah Mondial, IImu-IImu Sosial Dan Kemasyarakatan, 11 (19) Januari-J uni 2009, Universitas Syiah Kuala Aceh, hlm. 123.
}

segala bentuk kekerasan, eksploitasi dan diskriminasi; keempat, membangun lingkungan yang kondusif untuk menghargai pendapat anak dan memberi kesempatan untuk berpartisipasi sesuai dengan usia dan tahap perkembangan anak.

Pemerintah Provinsi Nanggroe Aceh Darussalam dalam upaya meningkatkan jangkauan pelayanan kesehatan sampai dengan tahun 2010 telah membangun sarana kesehatan berupa puskesmas-puskesmas Pembantu, Puskesmas Keliling, Rumah Sakit Umum, Rumah Sakit Ibu dan Anak, disertai penempatan tenaga kesehatan di berbagai sarana tersebut dan bidan di desa. Namun demikian mutu pelayanan kesehatan masih belum optimal disebabkan oleh lemahnya manajemen, belum mantapnya pelayanan rujukan, kurangnya dukungan logistik dan biaya operasional, serta penyebaran sarana dan prasarana kesehatan belum merata.

Tingginya tingkat efisiensi sektor kesehatan di Provinsi Nanggroe Aceh Darussalam, bukan berarti Pemerintah Daerah Provinsi Nanggroe Aceh Darussalam harus puas, pemerintah daerah harus tetap meningkatkan kinerjanya melalui peningkatan program kesehatan yang berhubungan langsung dengan kondisi kesehatan masyarakat. pemerintah juga bisa lebih memberdayakan fungsi dari fasilitas kesehatan yang sudah ada agar semakin meningkatkan perannya dan meningkatkan pelayanan agar bisa dijangkau seluruh lapisan masyarakat. peningkatan status kesehatan tidak hanya dapat dilakukan pemerintah tetapi juga dibutuhkan peran serta warganya dengan cara meningkatkan kesadaran warga atas pentingnya kesehatan. ${ }^{3}$

Berdasarkan hal tersebut di atas, tampak masih terjadi pelanggaran yang dilakukan terhadap hak anak yang pada hakikatnya bertentangan dengan nilai-nilai yang terkandung di dalam falsafah negara terutama nilai-nilai ketuhanan, kemanusiaan, dan nilai keadilan yang

\footnotetext{
3 Andri Kurniawan, "Kebijakan dan Isu Kesehatan dalam Otonomi Daerah", Jurnal IImu Kanun XII (51) Agustus 2010, Hukum Fakultas Hukum Universitas Syiah Kuala Aceh, hlm. 471.
} 
merupakan komitmen bersama sebagai bangsa yang harus diwujudkan dalam konstitusi. ${ }^{4}$

\section{Pembahasan \\ Pelaksanaan Pemenuhan Hak Anak atas Ke- sehatan di dalam Masyarakat.}

Berdasarkan prinsip hukum keluarga, setiap orang tua bertanggung jawab dalam memenuhi kebutuhan anak-anaknya, agar dapat tumbuh kembang secara wajar sesuai dengan kemampuannya. Apabila orang tuanya sudah tidak ada dan tidak mampu melaksanakan kewajibannya tersebut, keluarga sedarah dapat memenuhinya demi kepentingan terbaik anak. Bila tidak ada, maka pihak ketiga dapat melaksanakan kewajiban dan tanggung jawab tersebut sesuai dengan peraturan hukum yang berlaku. Sedangkan dalam mukadimah konvensi hak-hak anak disebutkan bahwa "keluarga sebagai kelompok inti dari masyarakat dan sebagai lingkungan alami bagi pertumbuhan dan kesejahteraan seluruh anggotanya terutama anak-anak harus diberi perlindungan dan bantuan yang dibutuhkan agar dapat memiliki sepenuhnya tanggung jawabnya dalam masyarakat. ${ }^{5}$

Sehubungan dengan itu, negara menjamin bahwa apabila anak tidak mempunyai keluarga dan membutuhkan bantuan dalam memenuhinya, maka negara menjamin dan memberikan perlindungan hukum sebagaimana di sebutkan di dalam Undang-Undang Dasar 1945 Pasal 28 B ayat (2) jo Pasal 28 A sebagai landasan konstitusional. Tujuan pemerintah adalah untuk melindungi hak anak atas kesehatan bagi anak dapat diartikan sebagai upaya perlindungan hukum terhadap berbagai kebebasan dan hak asasi anak (fundamental rights and freedoms of children) serta berbagai kepentingan yang berhubungan dengan kesejahteraan anak. J adi masalah perlindungan hukum bagi anak mencakup lingkup yang sangat luas. Didasarkan dari pem-

Bandingkan dengan Ratnaningsih, "Perlindungan Hukum Anak Dalam era Industrialisasi", Jurnal IImiah Hukum Legality 4 (1) 2006, Fakultas Hukum Universitas Muhammadiyah Malang, hlm. 23-36.

5 Kadriah, "Tanggung J awab Orang Tua Terhadap Anak Setelah Perceraian", J urnal IImu Hukum Kanun VII (18) Desember 1997, Fakultas Hukum Universitas Syiah Kuala, hlm. 40 batasan tersebut, maka lingkup perlindungan hukum bagi anak mencakup perlindungan terhadap kebebasan anak, perlindungan terhadap hak asasi anak dan perlindungan hukum terhadap semua kepentingan anak yang berkaitan dengan kesejahteraan.

Untuk menjamin perlindungan hak anak atas kesehatan, pemerintah menyediakan fasilitas dan menyelenggarakan upaya kesehatan yang komprehensif bagi anak, agar setiap anak memperoleh derajat kesehatan yang optimal sejak dalam kandungan. Penyediaan fasilitas dan penyelenggaraan upaya kesehatan secara komprehensif didukung oleh peran serta masyarakat. Upaya kesehatan itu meliputi promotif, preventif, kuratif, dan rehabilitatif. Orang tua dan keluarga secara prinsip bertanggung jawab menjaga kesehatan anak dan merawat anak. Jika mereka tidak mampu melaksanakan tanggung jawab tersebut, maka pemerintah yang wajib memeliharanya.

Tindak kekerasan terhadap anak bukan mustahil akan terus muncul dengan berbagai sebab. Bahkan ketika dilahirkan pun, dalam keadaan kekurangan gizi. Kekerasan terhadap anak bisa terjadi dimana saja bahkan di kalangan menengah ke bawah, kekerasan terhadap anak karena faktor kemiskinan. Di kalangan menengah ke atas, karena ambisi orang tua untuk menjadikan anaknya yang terbaik, di sekolah, di masyarakat.

Ada beberapa kelompok anak yang memerlukan perlindungan khusus. Pertama, anak yang berada dalam keadaan darurat yaitu pengungsi anak, anak yang berada dalam konflik bersenjata. Kedua, anak yang mengalami konflik hukum, yang menyangkut soal: administratif pengadilan anak, perenggutan kebebasan anak, penjatuhan hukuman terhadap anak, pemulihan kondisi fisik dan psikologis anak. Ketiga, anak dalam situasi eksploitasi yang meliputi Eksploitasi ekonomi, penyalahgunaan narkotika dan obat-obat terlarang, eksploitasi kekerasan seksual, penjualan, perdagangan, penculikan anak, dan eksploitasi dalam bentuk 
lainnya. Keempat, anak-anak dari kelompok minoritas dan masyarakat adat. ${ }^{6}$

Perangkat hukum yang ada di Indonesia sudah cukup memadai untuk perlindungan hakhak asasi anak, namun pemerintah dan masyarakat belum sepenuhnya dapat melaksanakan perlindungan terhadap hak asasi anak tersebut. Hal ini disebabkan belum meratanya kemampuan ekonomi dan sosial dalam masyarakat, sehingga masih banyak orang tua yang tidak dapat melaksanakan kewajibannya untuk memelihara dan mengadakan fasilitas-fasilitas yang diperlukan untuk pengembangan jasmani dan rohani anak. Hal ini dapat dilihat dari masih banyaknya anak-anak yang terlantar yang disebabkan karena keadaan orang tuanya yang tidak mampu atau anak-anak yang tidak mempunyai orang tua.

Kendati diketahui dan diakui bahwa di Indonesia telah dan sedang terjadi berbagai kasus eksploitasi, penganiayaan, dan pembunuhan terhadap anak-anak, namun sampai saat ini belum ada data yang secara rinci mampu menunjukkan bagaimana sebenarnya gambaran dan peta permasalahan kasus-kasus tindak pidana pelanggaran hak asasi anak. Dalam banyak kejadian, sekalipun tetangganya tahu dan mendengar jerit kesakitan dan tangis keras anakanak yang mengalami kekerasan oleh orang tuanya, tetapi karena persoalan itu dianggap masalah interen keluarga masing-masing, maka biasanya hanya diam dan tidak berani ikut mencampurinya. Dikalangan keluarga itu sendiri pun biasanya mereka juga enggan mengungkapkan kasus-kasus child abuse yang menimpa anggota keluarganya, karena dikhawatirkan akan dapat mempermalukan keluarganya atau menimbul-kan aib yang tidak diinginkan.

Tindak kekerasan terhadap anak-anak biasanya baru memperoleh perhatian publik secara lebih serius karena korban tindak kekerasan yang dilakukan orang dewasa kepada anak-anak jumlahnya semakin meluas, korban bertambah banyak dan menimbulkan dampak

6 M. Iqbal, "Kekerasan Terhadap Anak", J urnal IImiah Mondial IImu-IImu Sosial Dan Kemasyarakatan 9 (16) J uli-Desember 2007, Universitas Syiah Kuala Aceh, hlm. 53. yang sangat menyengsarakan anak-anak. Seperti halnya tindak kekerasan terhadap perempuan, tindak kekerasan yang dialami oleh anakanak terdapat pada setiap tingkatan, dapat dialami dan dilakukan oleh siapa saja baik oleh orang-orang yang secara psikologis berperilaku menyimpang atau oleh orang tua kandung sendiri yang sehari-hari terlihat begitu baik akan tetapi tiba-tiba menjadi kalap, memaki, menampar, memukul, atau bahkan membunuh anak kandungnya sendiri.

Tindak kekerasan yang dialami oleh anakanak sebenarnya tidak selalu berupa tindakan brutal, sadis dan kejam seperti memperkosa anak atau menganiaya anak hingga meninggal dunia. Tindak kekerasan yang dialami oleh anak-anak mungkin saja hanya terbatas pada tindakan memaki, penelantaran, pengabaian, mengancam, mengeksploitasi atau tindakantindakan lain yang mengakibatkan penderitaan psikologis yang menimbulkan bekas luka fisik, seperti luka memar, patah tulang, atau kematian anak.

Anak - dalam struktur masyarakat atau keluarga dimanapun di dunia ini - sesungguhnya adalah salah satu anggota komunitas yang memiliki posisi paling lemah dan rentan, sehingga sudah sewajarnya bila mereka membutuhkan kasih sayang, belas kasihan dan perlindungan yang cukup, terutama dari orang tua, masyarakat, dan pemerintah. Akan tetapi ironinya adalah kelemahannya dan kerentanan mereka itu, anak-anak seringkali menjadi korban dari hirarkhi masyarakat yang timpang dan tidak jarang mereka menjadi sasaran dari pelampiasan kekesalan, kemarahan dan kesewenang-wenangan para orang dewasa tidak terkecuali dari orang tuanya sendiri.

Secara umum, anak yang menjadi korban dari tindak kekerasan sebetulnya tidak dibatasi oleh perbedaan jenis kelamin, baik anak lakilaki maupun anak perempuan karena keduanya potensial dan merupakan sasaran dari perlakuan semena-mena yang berkembang di masyarakat. Kekerasan terhadap anak adalah semua bentuk kekerasan terhadap anak yang dilakukan oleh mereka yang seharusnya bertanggung ja- 
wab atas anak tersebut, yang seharusnya dapat dipercayai misalnya orangtua, guru dan orang terdekat lainnya. Kekerasan terhadap anak dapat terjadi di mana saja, di rumah, tempat bermain, atau bahkan di sekolah. Banyak kasus terjadi kekerasan dilakukan oleh orang-orang terdekat, yang semestinya memberikan perlindungan dan kasih sayang. ${ }^{7}$

Penegakan hukum atas kekerasan terhadap anak di Provinsi Nanggroe Aceh Darussalam masih berada dalam posisi yang masih rendah. Hal ini di karena adanya keterbatasan aparat penegak hukum dalam menelaah dan menafsirkan hukum sehingga masih banyak di kalangan penegak hukum yang masih memakai KUHP dalam tuntutannya dipersidangan padahal aturan tentang perlindungan anak sudah terakomodir semuanya dalam Qanun Aceh No. 11 Tahun 2008 Tentang Perlindungan Anak. Harmonisasi berbagai perundangan yang memberikan perlindungan kepada dihadapkan pada berbagai hambatan dan sosialisasi Peraturan perundangan kepada masyarakat belum sepenuhnya dapat dilakukan dengan baik. ${ }^{8}$ Di Indonesia masih sering anak-anak terpaksa harus membantu perekonomian rumah tangga orang tuanya, tidak mendapatkan pelayanan kesehatan yang layak, serta sulit untuk menikmati pendidikan yang layak dan memadai.

Pemerintah telah membuat perundangundangan yang mewajibkan anak-anak untuk sekolah (wajib belajar) dan telah berusaha untuk mengatasi masalah tersebut cara mendirikan puskesmas dan sekolah dasar, namun masih ada saja sekolah yang masih sulit mencari murid atau menyesuaikan waktu belajar dengan waktu untuk membantu orang tuanya bekerja. Hal ini dapat terjadi karena kemiskinan yang dihadapi oleh orang tuanya dan tetangga sekelilingnya mengkondisikan anak-anak untuk menjalankan peran yang sesungguhnya diluar kemampuan anak itu sendiri.

$7 \quad$ M. Iqbal Rani, "Perlindungan Hukum terhadap Hak Anak sebagai Korban Tindak Pidana Kekerasan", J urnal IImu Hukum Kanun IX (48) Desember 2009, Fakultas Hukum Universitas Syiah Kuala Aceh, hlm. 457.

8 M. Iqbal, "Kekerasan Terhadap Anak", Jurnal IImu Hukum Kanun XIIIV (43) April 2008, Fakultas Hukum Universitas Syiah Kuala Aceh, hlm. 65-66.
Nilai-nilai pengabdian dan kepatuhan kepada orang tua tertanam sedemikian rupa sehingga anak sering harus bekerja guna mendapatkan tambahan bagi pendapatan rumah tangga orang tuanya. Orang tua mengharapkan hal yang baik bagi masa depan anak-anaknya tetapi hal tersebut dipengaruhi oleh realitas hidup dan tantangan mereka hadapi sehari-hari.

Lahirnya Qanun Aceh No. 11 Tahun 2008 Tentang Perlindungan Anak, hak-hak anak di Provinsi Nanggroe Aceh Darussalam diharapkan semakin terlindungi. Walaupun telah memiliki perangkat hukum yang cukup memadai yang mengatur hal-hal yang berkaitan dengan perlindungan hak asasi anak oleh Qanun Aceh No. 11 Tahun 2008 tentang Perlindungan Anak, ternyata perlindungan terhadap anak belum dapat dilaksanakan sepenuhnya. Hal ini disebabkan belum meratanya kemampuan sosial dan ekonomi masyarakat, sehingga masih banyak orang tua yang tidak dapat melaksanakan kewajibannya untuk memelihara dan mengadakan fasilitas-fasilitas yang diperlukan untuk pengembangan jasmani, rohani dan sosial anak. Hal ini dapat dilihat dengan masih banyaknya anakanak yang telantar yang disebabkan keadaan orang tuanya yang tidak mampu atau anak-anak yang tidak mempunyai orang tua. ${ }^{9}$

Tabel 1

\section{Situasi Anak di Nanggroe Aceh Darussalam}

\begin{tabular}{|c|l|c|}
\hline No & \multicolumn{1}{|c|}{ Kasus } & Jumlah \\
\hline 1. & Perebutan Anak & 5 \\
2. & Gangguan J iwa & 2 \\
3. & Perkosaan & 4 \\
4. & Traficking & 1 \\
5. & Anak Terlantar & 7 \\
6. & Korban Tsunami yang ditemukan & 2 \\
& di luar Aceh & \\
7. & Penganiayaan & 1 \\
8. & Narkoba & 1 \\
9. & Telesemenia & 1 \\
10. & Pengusiran dari Desa & 1 \\
11. & Pelecehan Seksual & 1 \\
12. & Pekerja Anak & 2 \\
13. & Penemuan Anak & 5 \\
14. & Melarikan Anak & 1 \\
15. & Pengusiran dari sekolah & 1 \\
\hline
\end{tabular}

Sumber: Komisi Perlindungan Anak Indonesia Daerah NAD 2009

Tarmizi, Op.cit, hlm. 124. 
Anak-anak terlantar sebagai bagian yang tidak terpisahkan dari anak-anak bangsa ini, merupakan aset masa depan yang perlu dilindungi dan dibina untuk meraih masa depan yang lebih baik. Tanggung jawab perlindungan dan pembinaannya itu telah digariskan dalam berbagai peraturan perundang-undangan. Peraturan perundang-undangan ini dapat dipergunakan sebagai dasar hukum yang kuat bagi setiap usaha atau kegiatan yang berhubungan dengan perlindungan dan pembinaan anak terlantar.

Hukum hanya merupakan salah satu aspek lainnya yang berhubungan dengan permasalahan anak terlantar, seperti aspek ekonomi, politik dan budaya. Oleh karena itu, implementasi perlindungan dan pembinaan anak terlantar secara komprehensif harus meliputi semua aspek tersebut, sehingga tanggung jawab pemerintah dan masyarakat dalam pembinaan anak terlantar benar-benar terwuj ud. ${ }^{10}$

\section{Upaya Pemenuhan Hak Anak atas Kesehatan di Provinsi Nanggroe Aceh Darussalam.}

Seperti diketahui bahwa negara sudah mengatur tentang perkawinan dan hidup kekeluargaan. Dalam kaitan ini, perkawinan sangat penting dalam kehidupan manusia karena dengan perkawinan yang sah mengakibatkan pergaulan antara laki-laki dan perempuan menjadi sah. Sementara anak hasil keturunan perkawinan sah yang menghiasi kehidupan berumah tangga merupakan perhiasan kehidupan berumah tangga sekaligus merupakan kelangsungan hidup manusia secara bersih dan terhormat. ${ }^{11}$ Permasalahan kemudian timbul tatkala anak kemudian dibiarkan oleh orang tuanya dan menjadi terlantar.

Salah satu contoh yang terjadi di Provinsi Nanggroe Aceh Darussalam adalah terhadap anak jalanan yang merupakan suatu komunitas

10 Basri, "Tanggung Jawab Pemerintah dan Masyarakat dalam Pembinaan Anak Terlantar", Jurnal IImu Hukum Kanun XIIV (42) Agustus 2005, Fakultas Hukum Universitas Syiah Kuala Aceh, hlm. 347.

11 Tri Lisiani Prihatinah, "Tinjauan Filosofis UndangUndang Nomor 1 Tahun 1974", J urnal Dinamika Hukum 8 (2) Mei 2008, FH Universitas Jenderal Soedirman Purwokerto, hlm. 167 anak yang unik di kawasan perkotaan. Mereka memiliki kultur tersendiri yang spesifik dan berbeda dengan anak-anak normal. Pentingnya perlindungan bagi anak jalanan berkaitan dengan pengakuan eksistensinya sebagai anak dan tidak di diskriminasi dalam memperoleh akses terhadap hak-haknya seperti pendidikan, kesehatan, informasi, berserikat, namun tidak ada jaminan pemerintah daerah atas akses anak jalanan terhadap hak-hak anak di atas dengan mewajibkan menyediakan fasilitas umum. Dalam kaitan ini, sebab anak turun ke jalanan didasari oleh berbagai macam alasan meliputi membantu pekerjaan orang tua, kekurangan biaya sekolah, putus sekolah, tidak ada keterampilan lain dan tidak ada tempat lain untuk bekerja, terpisah dari orang tua, di paksa oleh orang tua, tidak tahan atas perilaku orang tua, mencari tema, mencari pengalaman dan ingin hidup bebas.

Terlepas dari penyebab yang disebutkan di atas, yang pasti anak-anak jalanan sering mengalami perlakuan tidak semestinya. Masyarakat umum dan pembuat kebijakan seringkali gagal memahami kehidupan anak-anak jalanan. Tindakan kekerasan terhadap anak jalanan dapat berupa pemukulan, penyiksaan, terserempet dan tertabrak kendaraan.

Perlindungan terhadap hak asasi anak di Provinsi Nanggroe Aceh Darussalam belum dapat dilaksanakan sepenuhnya, hal ini disebabkan belum meratanya kemampuan ekonomi dan sosial di dalam masyarakat. Pelanggaran hak asasi anak dapat terjadi dalam berbagai bentuk, seperti: perkosaan, trafficking, anak terlantar, penganiayaan, pengusiran dari desa (gampong), dan pekerja anak.

Tantangan yang dihadapi sekarang adalah bagaimana mengubah kerangka kerja hukum kedalam peraturan-peraturan untuk mendukung kebijakan yang dibuat, sehingga dapat diimplementasikan untuk menciptakan lingkungan yang melindungi anak-anak di Provinsi Nanggroe Aceh Darussalam secara berkelanjutan. Salah satu bagian dari Qanun Aceh No. 11 Tahun 2008 Tentang Perlindungan Anak tersebut adalah tidak memusatkan pada pengasuhan anak da- 
lam keluarga, lembaga pendidikan dan tidak menekankan pentingnya pengawasan dalam perwalian untuk anak-anak Muslim yang memiliki adat istiadat dan norma-norma tersendiri.

Qanun Aceh No. 11 Tahun 2008 Tentang Perlindungan Anak tidak menggarisbawahi komitmen untuk tidak menggunakan kekerasan fisik dan psikologis dalam mengajarkan nilainilai agama, tidak menyoroti pentingnya mengembangkan sistem rujukan, perlindungan dan pelayanan bagi korban kekerasan tidak dalam sebuah sistem terpadu dan dipungut biaya serta tidak melibatkan peran badan pengawas independen, seperti Badan Pemberdayaan Perempuan dan Perlindungan Anak Pemerintah Aceh, sebagai perpanjangan tangan Kementerian Pemberdayaan Perempuan dan Perlindungan tingkat nasional karena pengembangan lebih lanjut peraturan teknis dan advokasi untuk menjamin pelaksanaan Qanun Aceh No. 11 Tahun 2008 Tentang Perlindungan Anak tersebut tidak dilaksanakan bersama Badan Pemberdayaan Perempuan dan Perlindungan Anak serta Dinas Sosial Aceh. ${ }^{12}$

Provinsi Nanggroe Aceh Darussalam sejak tahun 2008 telah melahirkan Qanun Aceh No. 11 Tahun 2008 Tentang Perlindungan Anak, akan tetapi di lapangan masih terlihat belum ada kemajuan dan berpengaruh dalam pelaksanaan qanun perlindungan anak terhadap pekerja anak dan anak jalanan, keterlibatan dalam penggunaan dan penjualan ganja, anak penyandang cacat, Perdagangan Anak (Child Trafficking), Pengasuhan anak, dan perwalian.

\section{Pekerja Anak dan Anak J alanan}

Pekerja anak dan anak jalanan berkembang sebelum Tsunami. Hal ini terjadi karena terbatasnya kesempatan untuk mengikuti pendidikan dan keterbatasan ekonomi orang tua, yang mengakibatkan anak harus ikut bekerja sejak dini. Beberapa penelitian yang dilakukan di Aceh menyatakan beberapa hal. Pertama, anak-anak di pesisir pantainya umumnya memiliki kesempatan yang terbatas untuk akses se-

\footnotetext{
12 Basri. Loc.cit
}

kolah, mengingat di daerah ini terbatas jumlah guru. Ditemukan pada daerah pantai banyak anak yang bekerja sebagai penyelam lobster, nelayan, dan kuli pelabuhan. Dalam penelitian yang dilakukan oleh Pusat Kajian Perlindungan Anak (PKPA), penyelam lobster berisiko di Pulau Aceh berisiko tenggelam atau kecelakaan selama penyelaman, mengingat mereka hanya menggunakan kompresor untuk membantu pernafasan. Keterlibatan anak bekerja di sektor pertanian, mengingat anak telah dibiasakan bekerja sejak dini, disamping itu pada kepulauan dan pantai, guru yang mengajar di daerah ini sangat terbatas. Selama proses rehabilitasi dan rekonstruksi pasca Tsunami, banyak guru yang terlibat dalam proyek-proyek rekonstruksi, hal ini yang menyebabkan banyak guru-guru yang tidak mengajar. Kedua, dari penelitian yang di lakukan PKPA dan ILO-IPEC, terlihat anak yang bekerja di jalanan dan mengemis di Banda Aceh meningkat jumlahnya selama masa rehabilitasi dan rekonstruksi. Sebanyak 110 anak-anak baik dari Banda Aceh maupun dari daerah-daerah datang secara musiman atau menetap untuk mengemis. Mereka datang dari Lhokseumawe, Aceh Besar, dan beberapa kabupaten lain. Umumnya mereka ditemani oleh orang tua selama mengemis. Terdapat suatu pola yang dapat menumbuhkan pengemis di Banda Aceh, karena adanya anggapan "Tangan di Atas Lebih Baik daripada Tangan dibawah". Umumnya mereka tidak sampai hati untuk tidak memberi kepada pengemis. Hal ini yang menumbuhkan anak-anak untuk tetap di jalan. ${ }^{13}$ Ketiga, dari data Sensus Penduduk Aceh dan Nias tahun 2005, terlihat jumlah anak yang bekerja di bawah 15 tahun terdapat 17,279 orang yang tersebar di 21 kabupaten di NAD. Dari Konvensi ILO 138, ditetapkan bahwa batas minimum anak bekerja adalah 15 tahun. ${ }^{14}$

\section{Keterlibatan dalam Penggunaan dan Penjual- an Ganja}

13 Mapping Anak Jalanan di Banda Aceh dan Sekitarnya, 2006, Kerjasama PKPA, Dinsos dan ILO-IPEC.

14 Sensus Penduduk Aceh dan Nias, 2005, Badan Pusat Statistik. 
Keterlibatan anak dalam ganja disebabkan secara kultural ganja banyak dikonsumsi oleh masyarakat, baik untuk rokok maupun campuran makanan. Disamping itu, ganja cukup mudah diperoleh. Banyak anak-anak yang sejak Sekolah Dasar di daerah pantai sudah mengkonsumsi ganja sejak dini. ${ }^{15}$ Para ulama sendiri berbeda pendapat mengenai penggunaan ganja, sebagian ulama menganggap makruh artinya halal namun tidak boleh berlebihan, sebagian lagi menganggap haram. Aceh dikenal sebagai sumber pengiriman ganja ke daerah lain. Dari beberapa penangkapan penjual ganja, banyak yang berasal dari daerah ini.

\section{Anak Penyandang Cacat}

Setelah gempa dan Tsunami, banyak anak yang mengalami cedera, trauma dan shock akibat bencana ini. Banyak dari yang mengalami cedera ini kemudian menjadi cacat tetap. Laporan ahli dalam penanganan bencana mengindikasi jumlah yang cukup besar dari sakit dan diamputasi. Kelompok cacat adalah kelompok yang paling terabaikan. Penelitian menunjukkan bahwa bencana alam, ada beberapa kelompok di masyarakat yang mengalami diskriminasi dalam distribusi bantuan, rentan terhadap kekerasan, tindakan yang menyakitkan, dan penyimpangan atas hak asasinya. Rentan dalam hal ini disebabkan karena kecacatan mereka, gender, lokasi geografis, etnik, usia dan status sosial di masyarakat. Beberapa anak di sekolah tidak dapat mengikuti pendidikan karena anak memiliki kecacatan yang membuat mereka tidak bisa mengikuti pelajaran dibandingkan anak-anak lain; seperti mata rabun, cacat fisik, rendahnya kemampuan mendengar dan lainlain.

\section{Perdagangan Anak (Child Trafficking)}

Banyak faktor yang menyebabkan kejahatan perdagangan anak semakin marak terjadi dan terus berkembang dari waktu ke waktu. Dalam makalah Pemenuhan dan Perlindungan

15 Wawancara Terhadap Nelayan atas Penggunaan Ganja di Kalangan Nelayan, Februari, 2011. Mapping Anak J alanan di Banda Aceh dan Sekitarnya, 2006, Kerjasama PKPA, Dinsos dan ILO-IPEC.
Hak terhadap Korban Perdagangan Manusia (Human Trafficking) yang dihimpun oleh $\mathrm{A}$. Hadi Utomo ${ }^{16}$, memaparkan 7 (tujuh) faktor penyebab terjadinya perdagangan manusia (Human Trafficking).

Pertama, kurangnya kesadaran, banyak orang bermigrasi untuk mencari kerja baik di Indonesia ataupun di luar negeri tidak mengetahui adanya bahaya trafficking dan tidak mengetahui cara-cara yang dipakai untuk menipu atau menjebak mereka dalam pekerjaan yang disewenang-wenangkan atau pekerjaan yang mirip perbudakan. Kedua, kemiskinan, kemiskinan telah memaksa banyak keluarga untuk merencanakan strategi penopang kehidupan mereka termasuk bermigrasi untuk bekerja dan bekerja karena jeratan hutang, yaitu pekerjaan yang dilakukan seseorang guna membayar hutang atau pinjaman. Ketiga, keinginan cepat kaya (materialistic), keinginan untuk memiliki materi dan standar hidup yang lebih tinggi-memicu terjadinya migrasi dan membuat orangorang yang bermigrasi rentan terhadap trafficking.

Keempat, faktor budaya, faktor-faktor budaya berikut memberikan kontribusi terhadap terjadinya trafficking, seperti (a) Peran perempuan dalam keluarga, meskipun normanorma budaya menekankan bahwa tempat perempuan adalah dirumah sebagai istri dan ibu, juga diakui bahwa perempuan seringkali menjadi pencari nafkah tambahan/pelengkap kebu-tuhan keluarga. Rasa tanggungjawab dan kewajiban membuat banyak wanita bermigrasi untuk bekerja agar dapat membantu keluarga mereka; (b) Peran anak dalam keluarga, kepatuhan terhadap orangtua dan kewajiban keluarga membuat anak-anak rentan terhadap trafficking. Buruh atau pekerja anak, anak berimigrasi untuk bekerja dan buruh anak karena jeratan hutang dianggap sebagai strategistrategi keuangan keluarga yang dapat diterima untuk dapat menopang kehidupan keuangan keluarga; (c). Perkawinan dini, perkawinan dini

16 A. Hadi Utomo, 1999, Pemenuhan dan Perlindungan Hak Terhadap Korban Trafficking, Bandung: Yayasan Bahtera, hlm. 5. 
mempunyai implikasi yang serius bagi para anak perempuan termasuk bahaya kesehatan, putus sekolah, kesempatan ekonomi yang terbatas, gangguan perkembangan pribadi dan seringkali juga perceraian dini. Anak-anak perempuan yang sudah bercerai secara sah dianggap sebagai orang dewasa dan rentan terhadap trafficking disebabkan oleh kerapuhan ekonomi mereka; (d) Sejarah pekerjaan karena jeratan hutang, praktik menyewakan tenaga anggota keluarga untuk melunasi pinjaman merupakan strategi penopang kehidupan keluarga yang dapat dite-rima oleh masyarakat. Orang yang ditempatkan sebagai buruh karena jeratan hutang khusus-nya, rentan terhadap kondisikondisi yang se-wenang-wenang dan mirip dengan perbudakan.

Kelima, kurangnya pencatatan kelahiran, orang tanpa tanda pengenal yang memadai lebih mudah menjadi mangsa trafficking karena usia dan kewarganegaraan mereka tidak terdokumentasi. Anak-anak yang diperdagangkan, misalnya lebih mudah diwalikan kepada orang dewasa maupun yang memintanya. Keenam, kurangnya pendidikan, orang dengan pendidikan yang terbatas, memiliki lebih sedikit keahlian (skill) dan kesempatan kerja dan mereka lebih mudah menjadi korban trafficking karena mereka bermigrasi mencari pekerjaan yang tidak membutuhkan keahlian. Ketujuh, lemahnya penegakan hukum, pejabat penegak hukum tidak memperdulikan kegiatan-kegiatan yang bersifat kriminal, dimana para pejabat pemerintah dapat juga disuap agar memberikan informasi yang tidak benar pada Kartu Tanda Penduduk (KTP), akte kelahiran dan paspor.

Terre des Hommes, ${ }^{17}$ memaparkan lebih lanj ut tentang faktor-faktor penyebab mengapa anak-anak tersedia bagi para trafikker (seseorang atau suatu kesatuan yang melakukan atau terlibat dalam tindakan trafficking). Pertama, poverty, globalisation, and restrictions on migration, kemiskinan yang dapat menyebabkan kemelaratan, pengaruh globalisasi yang mendesak para buruh terutama yang

17 Terre De Hommes, 2004, Kids As Commodities? Child Trafficking And What To Do About It, hlm. 28-31. berasal dari negara-negara miskin melakukan migrasi untuk mencari pekerjaan agar dapat menghidupi keluarga mereka. kedua, Low of Education, rendahnya tingkat pendidikan anak diberbagai negara miskin, melahirkan rendahnya kualitas intelektual generasi muda negara tersebut, sehingga tidak memiliki daya saing bila dibandingkan dengan kualitas intelektual yang dimiliki generasi muda di negara-negara kaya. Rendahnya kualitas intelektual tersebut, memaksa anak-anak itu mencari alternatif pekerjaan lainnya, walaupun dengan upah yang minim. Sehingga mereka masuk kedalam wilayah pekerjaan yang rentan terhadap praktikpraktik kejahatan Perdagangan Anak (Child Trafficking). Ketiga, faktor sosial lainnya, seperti discrimination, adanya faktor diskriminasi terhadap beberapa jenis ras dan komunitas tertentu didunia dan cultural norms, pada berbagai belahan dunia, suatu komunitas masyarakat tertentu masih menerapkan berbagai diskriminasi terhadap perempuan dalam hal perjodohan. Beberapa hukum kebiasaan di beberapa negara masih menerapkan metode marriage-related atau sistem perjodohan dalam memilih pasangan hidup bagi anak perempuannya. Hal ini menyebabkan banyak anak perempuan yang memutuskan untuk melarikan diri dari keluarganya. Pada hukum kebiasaan lainnya, beberapa komunitas masyarakat masih menggunakan payment systems surrounding marriage atau sistem pembayaran dalam perkawinan, dimana mahar/mas kawin yang disiapkan pihak laki-laki adalah tebusan untuk perempuan yang akan dinikahinya. Keempat, Domestic Violence, unmaried women atau single parents merupakan salah satu alasan yang membuat anak mereka menjadi objek adopsi di beberapa negara. Pada sisi lainnya, anak yang mengalami kekerasan baik seksual maupun fisik berulang-ulang lebih memiliki kecenderungan untuk meninggalkan rumah mereka dari pada anak yang tidak mengalami aneka kekerasan. Kelima, crises: natural and man-made, berbagai krisis terjadi didunia, baik yang terjadi karena bencana alam, konflik bersenjata mau pun menjalarnya berbagai penyakit menular 
seperti HIV/ AIDS. Bencana alam dan konflik bersenjata mengakibatkan besarnya arus perpindahan penduduk yang terjadi dari suatu negara ke negara lain, banyak anak yang terpisah dari orang tua dan keluarga mereka menjadikan mereka sebagai sasaran empuk perdagangan anak. Menjalarnya berbagai penyakit seperti HIV/ AIDS membunuh jutaan orang tua didunia dewasa ini, sehingga menelantarkan anak-anak mereka. Keenam, ambition and hope, cita-cita, impian hidup dan pengharapan yang dimiliki oleh orang tua dan anak memaksa para anak untuk merantau kedaerah lain dengan tujuan untuk mendapatkan penghasilan yang layak dan perubahan tingkat sosial ekonomi keluarga kearah yang lebih baik.

Menurut Rheny Wahyuni Pulungan, penyebab utama terjadinya kejahatan perdagangan anak ialah keterpurukan kondisi ekonomi Indonesia. Hal tersebut akan berdampak langsung pada penutupan banyak pabrik dan rasionalisasi besar-besaran terhadap jumlah tenaga kerja. Akibatnya, banyak orang yang kehilangan pekerjaan. Selain itu, akibat kurang kondusifnya iklim investasi terutama karena faktor keamanan, sedikit sekali lapangan kerja yang tersedia. Peluang kerja yang ada tidak sebanding dengan jumlah orang yang mencari pekerjaan. Keadaan ini membuat orang berupaya keras mencari pekerjaan hingga kenegara lain. Disisi lain, dilihat dalam konteks keluarga, perempuan dan anak dipandang sebagai "pekerja alternatif" yang dapat menjamin kelangsungan hidup satu keluarga.

Kedudukan perempuan dan anak yang tersubordinasi dalam struktur masyarakat yang patriarkis menyebabkan mereka kemudian menjadi sumber mata pencaharian keluarga. Akibat pendidikan dan keterampilan yang rendah, peluang kerja yang dapat mereka masuki adalah pekerjaan disektor non-formal. Dimana proses birokrasi yang berbelit dan ketidaksabaran menunggu proses administrasi menyebabkan banyak calon tenaga kerja meminta "jasa" kepihak ketiga untuk mengurus keberangkatannya secara ilegal yang akhirnya berkembang menjadi praktik perdagangan manusia.

\section{Pengasuhan Anak}

Anak-anak harus mendapatkan pemeliharaan dan pengasuhan yang layak dan tugas utama untuk melaksanakan itu ada pada orang tua/ keluarga. Dengan demikian, sangat jelas bahwa tempat yang terbaik bagi anak untuk hidup, tumbuh dan berkembang adalah bersama keluarganya. Untuk itu pemerintah dan juga masyarakat harus mengambil langkah-langkah nyata dalam memastikan dan mendorong keluarga untuk memberikan pengasuhan yang layak bagi anaknya.

Namun demikian ketika keluarga tidak berfungsi secara optimal dalam memberikan pengasuhan yang layak maka harus dicarikan alternatif lain agar anak tetap bisa tumbuh dan berkembang dengan baik. Konsep inilah yang disebut sebagai pengasuhan alternatif. Pengasuhan alternatif ini bisa dilakukan oleh seseorang, keluarga ataupun lembaga yang memenuhi persyaratan tertentu berdasarkan ketentuan Undang-Undang yang berlaku. Model pengasuhannya bisa berbasis keluarga maupun berbasis institusi. Namun apapun model pengasuhan yang akan diambil, pengasuhan berbasis institusi adalah pilihan terakhir dari semua pilihan yang tersedia karena tempat terbaik buat anak adalah dengan keluarganya.

Lembaga pengasuhan alternatif yang umum dikenal di Indonesia termasuk di Aceh adalah Panti. Dari data Dinas Sosial NAD maret 2005, tercatat 182 panti yang tersebar di 19 kabupaten/ kota di seluruh Aceh terdiri dari 168 panti untuk anak terlantar dan 14 panti untuk anak cacat. Namun pada tahun 2006, berdasarkan penelitian yang dilakukan oleh Save the Children dan Departemen sosial terjadi peningkatan jumlah menjadi 217 panti, 35 diantaranya tidak tercatat dalam data Dinsos dan 10 lainnya sudah tidak aktif lagi. Penelitian tersebut mencatat terdapat sekitar 15.888 anak tinggal dipanti. Namun, hanya $10 \%$ diantaranya yang merupakan yatim piatu. Penelitian tersebut juga mengungkapkan bahwa $95 \%$ panti asuhan dikelola oleh swasta, organisasi keagamaan dan organisasi kemasyarakatan. Hanya $5 \%$ yang merupakan milik pemerintah. Pendana- 
anya berasal dari swadaya masyarakat, organisasi donor, pemerintah (dana dekonsentrasi dan subsidi BBM) dan BRR. Untuk tahun anggaran 2007 BRR mengalokasikan anggaran sebesar 15 milyar untuk mendukung keberlangsungan panti.

\section{Perwalian}

Menurut hukum Indonesia, perwalian di definisikan sebagai kewenangan untuk melaksanakan perbuatan hukum demi kepentingan, atau atas nama, anak yang orang tuanya sudah meninggal, atau tidak mampu melakukan perbuatan hukum. Undang-Undang tentang perwalian mengatur tentang pengasuhan anak yatim serta pengelolaan harta hak waris anak yatim tersebut. Ketentuan tersebut diatur terutama dalam Undang-Undang No. 1 Tahun 1974 Tentang Perkawinan dan Kompilasi Hukum Islam. Di Aceh, pengadilan relavan yang mempunyai yurisdiksi atas persoalan perwalian adalah Mahkamah Syar'iyah,yang menerapkan Kompilasi Hukum Islam. Ada juga berapa fatwa sangat berpengaruh persoalan perwalian juga di atur dalam hukum adat. Namun hanya terdapat sedikit perbedaan antara hukum formal dan hukum adat, karena keduanya didasarkan pada prinsip Islam.

Pengadilan berwenang untuk menunjuk wali apabila orang tua anak yang bersangkutan telah meninggal atau tidak cakap melakukan perbuatan hukum. Orang tua dapat dianggap tidak cakap melakukan perbuatan hukum jika dibawah umur (dibawah 21 tahun), atau mengalami cacat fisik atau mental yang berat. Hukum Indonesia menyatakan secara tidak langsung bahwa perwalian hanya berlaku bagi anak yang kehilangan kedua orang tuanya. $\mathrm{Na}$ mun di masyarakat Aceh, seorang wali sering ditunjuk, bukan saja jika kedua orang tua meninggal, tetapi juga bila seorang ayah meninggal.

Menurut hukum di Indonesia, seorang wali bertanggung jawab atas kesejahteraan dan harta benda anak yang berada di bawah perwaliannya, termasuk warisan. Namun, cara yang digunakan untuk mengelola perwalian pada praktiknya lebih rumit. Di Aceh, Wali yang ditunjuk (biasanya laki-laki yang berasal dari sanak keluarga dari pihak ayahnya) pada umumnya hanya bertanggung jawab untuk mengelola harta benda anak di bawah perwaliannya. Untuk kesejahteraan, atau pengasuhan sehari-hari anak biasanya akan diberikan kepada ibu si anak tersebut, atau jika ibunya meninggal, biasanya perempuan dari pihak sanak keluarga ibu. Masyarakat Aceh juga mengakui jenis wali lainnya yang penting wali perkawinan yang bertanggung jawab untuk menyatakan persetujuan atas pernikahan pengantin perempuan dalam upacara perkawinan Islam. Di Aceh, wali perkawinan dan wali warisan biasanya adalah orang yang sama. Apabila kedua orang tua meninggal, maka dalam hal ini perempuan dari sanak keluarga pihak ibu akan memegang peranan sebagai pengasuh utama, sedangkan laki-laki dari sanak keluarga pihak ayah, biasanya seorang paman, ditunjuk sebagai wali warisan/ wali perkawinan.

Setelah Tsunami, mayoritas yang memegang tanggung jawab perwalian tidak di tunjuk secara resmi, tetapi dipilih berdasarkan persetujuan bersama dalam keluarga atau komunitas. Pemimpin desa biasanya akan diberitahukan tentang putusan tersebut, penunjukan biasanya dilakukan tidak resmi, dan hanya sedikit catatan. Namun, dalam kasus tertentu penunjukan wali dapat melibatkan proses adat. Dalam keadaan tersebut, upacara sederhana akan diselenggarakan, seringkali di meunasah atau tempat pertemuan gampong. Tujuan dari pertemuan itu adalah penetapan penunjukan dan memberitahu anggota komunitas tentang keadaan itu. Hanya apabila ada kasus, penunjukan wali akan diajukan kepada geuchik/atau imuem meunasah untuk di selesaikan.

Apabila seorang anak mempunyai warisan, seperti tanah atau uang, ada kecenderungan yang lebih besar untuk mencari pengakuan perwalian secara formal melalui sistem hukum yang formal. Hal ini sering dilakukan agar wali dapat mempunyai akses terhadap harta benda yang diwariskan terhadap anak dibawah perwaliannya, seperti rekening bank, atas nama 
anak tersebut. Agar hal ini dapat dilakukan, dan agar perwalian dianggap sah menurut hukum, seorang wali harus ditunjuk dan ditetapkan oleh pengadilan. Di Aceh pengadilan yang relevan adalah Mahkamah Syariah. Perwalian resmi dapat diberikan kepada seseorang, atau badan hukum seperti yayasan, lembaga pemerintah atau LSM. Di Aceh Baitul Mal (Kebendarahan Islam) dapat ditunjuk sebagai wali yang sah bagi seorang anak.

Wali yang ditunjuk harus berasal dari keluarga anak yatim. Jika tidak ada sanak keluarga yang dekat, seorang dewasa dari luar keluarga anak yatim dapat bertindak sebagai wali, asal orang tersebut memenuhi persyaratan kesehatan dan kepribadian. Persyaratan tersebut termasuk syarat bahwa wali harus seagama dengan agama yang dianut anak yang diasuhnya. Di Aceh, Baitul Mal dapat ditunjuk sebagai wali sah dari seorang anak. Namun ada keraguan tentang itu, karena Baitul Mal didirikan sbagai lembaga formal hanya melalui Keputusan Gubernur pada tahun 2003, dan pada saat ini Baitul Mal hanya berada di tingkat Provinsi dan Kabupaten/ Kota.

Tidak ada ketentuan dalam hukum Indonesia yang mencegah penunjukan perempuan sebagai wali atas anaknya sendiri, atau anak orang lain. Dalam kaitan ini, jika seorang ibu atau ayah meninggal, pasangannya yang masih hidup secara otomatis berdasarkan UndangUndang menjadi wali atas anak yang berusia di bawah 18 tahun. Akan tetapi dalam praktiknya di Aceh, hal semacam itu tidak terjadi, dimana ada pendapat bahwa perempuan tidak dapat ditunjuk sebagai wali. Akibatnya, apabila seorang ibu ingin mendapatkan pengakuan formal atas statusnya sebagai wali, dia harus mengajukan permohonan kepada Mahkamah Syar'iyah.

Berdasarkan hukum adat, apabila seorang ayah meninggal, ibu yang masih hidup secara otomatis menjadi wali dari anak-anak yang masih hidup. Dia juga bertanggung jawab atas harta benda yang diwariskan kepada anak, kecuali apabila dia dianggap tidak cakap untuk melakukan perbuatan hukum. Dalam kasus tersebut perempuan diberi kewenangan atas harta benda anak untuk menjamin bahwa anak itu diberi kewenangan atas harta bendanya dan untuk menjamin bahwa anak itu mendapat pengasuhan yang tepat serta perempuan tersebut tidak perlu bergantung pada keluarga suaminya yang telah meninggal untuk mendapatkan bantuan keuangan. Perempuan sebagai wali (voogdij) - maksudnya tanggung jawab untuk melindungi, mengasuh dan mengelola harta benda anak yang ditinggalkan oleh suaminya yang telah meninggal - dari perspektif adat, sepenuhnya sesuai dengan Hukum Islam dimana perempuan mempunyai status sama dengan lakilaki sebagai subyek hukum (personensrecht), supaya perempuan dianggap mampu menurut hukum dan cakap melakukan perbuatan hukum untuk menjadi wali, memberi perlindungan, pengawasan dan manfaat pada waris anak.

\section{Gambaran Umum Kebijakan Pemerintah Pro- vinsi Nanggroe Aceh Darussalam dalam Melin- dungi Hak Anak atas Kesehatan.}

Aceh, sejak tahun 2008 telah melahirkan Qanun Aceh No. 11 Tahun 2008 Tentang Perlindungan Anak, ada kemajuan dalam pembentukan qanun perlindungan anak, terutama terhadap anak-anak yang memerlukan perlindungan khusus. Anak yang memerlukan perlindungan khusus menjadi penting dilakukan oleh negara. Pemerintah Aceh dan pemerintah kabupaten/ kota untuk memberikan perlindungan pada anak masih memerlukan suatu Qanun mengenai perlindungan anak sebagai landasan yuridis bagi pelaksanaan kewajiban dan tanggungjawab tersebut. Dengan demikian pembentukan Qanun Aceh No. 11 Tahun 2008 Tentang Perlindungan Anak didasarkan pada pertimbangan bahwa perlindungan anak dalam segala aspeknya merupakan bagian dari kegiatan pembangunan kekhususan dan keistimewaan Aceh, memajukan kehidupan bermasyarakat dan berbangsa dalam Negara Kesatuan Republik Indonesia. Pasal 1 ayat (2) Qanun Aceh Nomor 11 Tahun 2008 Tentang Perlindungan anak, ditegaskan bahwa:

"Perlindungan anak adalah segala kegiatan untuk menjamin dan melindungi anak dan hak-haknya agar dapat hidup, tum- 
buh dan berkembang, dan berpartisipasi, secara optimal sesuai dengan harkat dan martabat kemanusiaan, serta mendapat perlindungan dari kekerasan dan diskriminasi".

Didasarkan rumusan yang disebutkan di atas, tampak adanya penekanan terhadap harkat dan martabat manusia yang mulia, bebas dan bertanggung jawab serta hormat kepada Tuhan Yang Maha Esa.

Dukungan kelembagaan dan peraturan perundang-undangan diperlukan untuk menjamin pelaksanaan perlindungan terhadap hakhak anak. Qanun Aceh No. 11 Tahun 2008 Tentang Perlindungan Anak menegaskan bahwa pertanggungjawaban orang tua, keluarga, masyarakat, pemerintah, dan negara merupakan rangakaian kegiatan yang dilaksanakan secara terus menerus demi terlindunginya hak-hak anak.

Upaya perlindungan anak harus dilaksanakan sedini mungkin, yakni sejak dari janin dalam kandungan. Qanun No. 11 Tahun 2008 Tentang Perlindungan Anak menjelaskan bahwa kewajiban memberikan perlindungan kepada anak berdasarkan asas-asas nondiskriminasi; kepentingan yang terbaik bagi anak; hak untuk hidup, kelangsungan hidup, dan perkembangan; dan penghargaan terhadap pendapat anak.

Perlindungan hukum bagi anak memiliki arti memberikan perlindungan kepada anak agar terlindungi dengan perangkat-perangkat hukum. Dengan kata lain, perlindungan hukum bagi anak merupakan upaya memberikan perlindungan secara hukum agar hak-hak maupun kewajiban anak dapat dilaksanakan pemenuhannya. Sehingga, di dalam perlindungan hukum bagi anak yang terutama ialah perlindungan hukum atas hak-hak anak, bukan kewajiban.

Ketentuan Pasal 39 ayat (3) Qanun Aceh No. 11 Tahun 2008 menegaskan bahwa, "Pemerintah Aceh dan Pemerintah kabupaten/kota berkewajiban menyediakan bantuan hukum terhadap anak-anak yang berhadapan dengan hukum". Bagi anak-anak yang berhadapan dengan tindak pidana, dapat diselesaikan di luar pengadilan dengan syarat: anak yang berumur
12 tahun ke bawah, ancaman hukumannya sampai dengan 1 (satu) tahun, akibat yang ditimbulkan dari tindak pidana tersebut bersifat kebendaan dan tidak terkait dengan tubuh dan nyawa, semua kasus pencurian yang tidak terkait dengan tubuh dan jiwa, dan perkelahian yang tidak menimbulkan cacat fisik dan kehilangan jiwa. Di Provinsi Nanggroe Aceh Darussalam, pemerintah bersama dengan organisasi non pemerintah (LSM) berperan penting dalam pemulihan dan reintegrasi anak-anak. Upaya pemulihan harus ditujukan kepada penegakan hukum yang menjadi bagian yang lemah. Seringkali pelaku eksploitasi dan konsumen anak tidak dihukum. Sebaliknya anak yang dieksplotasi sering diperlakukan secara tidak layak. Penegakan hukum atas pelanggaran hak asasi anak masih sulit diungkapkan karena adanya keterbatasan aparat dan tidak cukupnya anggaran untuk mencari tersangka dan buktibukti yang diajukan kepengadilan kurang meyakinkan hakim.

\section{Penutup \\ Simpulan}

Implementasi hak anak atas kesehatan ditemukan dalam ketetuan Pasal 1 ayat (2) Qanun Aceh No. 11 Tahun 2008 Tentang Perlindungan Anak bahwa perlindungan anak adalah kegiatan untuk menjamin dan melindungi anak dan hak-haknya agar dapat hidup, tumbuh dan berkembang, dan berpartisipasi, secara optimal sesuai dengan harkat dan martabat kemanusiaan, serta mendapat perlindungan dari kekerasan dan diskriminasi. Instansi atau lembaga Pemerintah Aceh bertanggung jawab dalam pelaksanaan pemenuhannya dengan menyelenggarakan antara lain: pemantapan kerjasama lintas sektor dalam rangka optimalisasi hasil pembangunan berwawasan kesehatan; peningkatan perilaku, kemandirian masyarakat dan kemitraan swasta dalam upaya kesehatan bagi anak; peningkatan kesehatan lingkungan dalam rangka mewujudkan lingkungan sehat bagi anak; peningkatan mutu dan keterjangkauan pelayanan kesehatan bagi anak; peningkatan sumberdaya kesehatan; peningkatan kebijakan dan 
pembangunan kesehatan; peningkatan perlindungan kesehatan masyarakat terhadap penggunaan sediaan farmasi, makanan, dan alat kesehatan; dan peningkatan mutu ilmu pengetahuan dan teknologi kesehatan. Oleh karena itu, faktor penghambat dalam pelaksanaan pemenuhan hak anak atas kesehatan antara lain: masih kurangnya fasilitas pelayanan kesehatan yang komprehensif, merata dan berkualitas, pemenuhan gizi seimbang, pencegahan penyakit menular termasuk HIV dan AIDS, pengembangan lingkungan dan perilaku hidup sehat; masih kurangnya pelayanan kesehatan yang merata, bermutu dan demokratis bagi semua anak sejak usia dini; masih kurangnya sistem pelayanan sosial dasar dan hukum yang responsif terhadap kebutuhan anak agar dapat melindungi anak dari segala bentuk kekerasan, eksploitasi dan diskriminasi; serta masih kurangnya pembangunan lingkungan yang kondusif untuk menghargai pendapat anak dan memberi kesempatan untuk berpartisipasi sesuai dengan usia dan tahap perkembangan anak.

Perlindungan hukum dalam pemenuhan hak anak atas kesehatan didasarkan Qanun Aceh No. 11 Tahun 2008 Tentang Perlindungan Anak dapat dilaksanakan sepanjang pelaksanaan melibatkan peningkatan kerjasama lintas sektor termasuk dukungan lembaga eksekutif dan legislatif di tingkat pusat, provinsi, dan kabupaten/kota, pemberdayaan orang tua dan/ atau wali anak, pemberdayaan masyarakat termasuk LSM, organisasi profesi dan kemitraan swasta dan penelitian dan pengembangan untuk mendukung program kesehatan dan kesejahteraan anak.

\section{Daftar Pustaka}

Basri. "Tanggung Jawab Pemerintah dan Masyarakat dalam Pembinaan Anak TerIantar". Jurnal IImu Hukum Kanun XIIV (42) Agustus 2005. FH Univ. Syiah Kuala Aceh;
BPS. 2005. Sensus Penduduk Aceh dan Nias. Badan Pusat Statistik;

Hambali. "Hak Anak atas Pendidikan; Pemenuhan Hak dan solusinya (Dimulai dari Pendidikan Keluarga dan aktivitas Sederhana)". J urnal Paradigma, XII (24) J uliDesember 2007. IKIP Budi Utomo Malang;

Iqbal Rani, M. "Perlindungan Hukum terhadap Hak Anak sebagai Korban Tindak Pidana Kekerasan". J urnal IImu Hukum Kanun IX (48) Desember 2009. Fakultas Hukum Universitas Syiah Kuala Aceh;

-.-.-.-. "Kekerasan Terhadap Anak". J urnal IImiah Mondial IImu-IImu Sosial \& Kemasyarakatan 9 (16) Juli-Desember 2007. Universitas Syiah Kuala Aceh;

"Kekerasan Terhadap Anak". Jurnal IImu Hukum Kanun XIIIV (43) April 2008. FH Universitas Syiah Kuala Aceh;

Kadriah. "Tanggung J awab Orang Tua Terhadap Anak Setelah Perceraian". J urnal IImu Hukum Kanun VII (18) Desember 1997. FH Universitas Syiah Kuala;

Kurniawan, Andri. "Kebijakan dan Isu Kesehatan dalam Otonomi Daerah". J urnal IImu Kanun XII (51) Agustus 2010. Fakultas Hukum Universitas Syiah Kuala Aceh;

Mapping Anak Jalanan di Banda Aceh dan Sekitarnya. 2006; Kerjasama PKPA, Dinsos dan ILO-IPEC;

Prihatinah, Tri Lisiani. "Tinjauan Filosofis Undang-Undang Nomor 1 Tahun 1974". J urnal Dinamika Hukum 8 (2) Mei 2008, FH UNSOED;

Ratnaningsih. "Perlindungan Hukum Anak dalam era Industrialisasi". Jurnal IImiah Hukum Legality 4 (1) 2006. FH Universitas Muhammadiyah Malang;

Tarmizi. "Penegakan Hukum Atas Pelanggaran Hak Asasi Anak di Banda Aceh". Jurnal IImiah Mondial, IImu-IImu Sosial dan Kemasyarakatan, 11 (19) J anuari-J uni 2009. Universitas Syiah Kuala Aceh;

Utomo, A. Hadi. 1999. Pemenuhan dan Perlindungan Hak Terhadap Korban Trafficking, Bandung: Yayasan Bahtera. 